\title{
PENGARUH NPL, CAR DAN BOPO TERHADAP PROFITABILITAS PADA BPR DI KOTA DENPASAR
}

\author{
Ni Kadek Alit Pradina Putri ${ }^{1}$ \\ Luh Putu Wiagustini' ${ }^{2}$ \\ Ni Nyoman Abundanti ${ }^{3}$
}

${ }^{1,2}$ Fakultas Ekonomi dan Bisnis Universitas Udayana (Unud), Bali, Indonesia

e-mail: pradinaputri1996@gmail.com

\begin{abstract}
ABSTRAK
Kinerja keuangan BPR dapat diukur oleh masyarakat melalui analisis terhadap laporan keuangan. Analisis terhadap laporan keuangan suatu bank dilakukan untuk mengetahui tingkat profitabilitas dan tingkat kesehatan bank tersebut. Tujuan dari penelitian ini adalah untuk mengetahui pengaruh Non Perfoming Loan, Capital Adequacy Ratio dan Biaya Operasioal Pendapatan Operasional terhadap profitabilitas pada Bank Perkreditan Rakyat di Kota Denpasar pada periode 2013-2016. Metode yang digunakan dalam penelitian ini adalah teknik analisis regresi berganda. Penelitian ini menggunakan sampel jenuh dengan mengambil sampel sebanyak 18 BPR yang ada di Kota Denpasar. Berdasarkan hasil analisis yang ditemukan bahwa Non Perfoming Loan memiliki pengaruh negatif signifikan terhadap profitabilitas, Capital Adequacy Ratio memiliki pengaruh positif signifikan terhadap profitabilitas, dan biaya operasional pendapatan operasional memiliki pengaruh negatif signifikan terhadap profitabilitas.
\end{abstract}

Kata kunci: NPL,CAR, BOPO, profitabilitas

\section{ABSTRACT}

$B P R$ financial performance can be measured by the community through analysis of financial statements. An analysis of the financial statements of a bank is conducted to determine the level of profitability and soundness of the bank. The purpose of this research is to know the influence of Non Perfoming Loan, Capital Adequacy Ratio and Operational Cost of Operational Revenue to profitability at Rural Bank in Denpasar in period 2013-2016. The method used in this research is multiple regression analysis technique. This research uses saturated samples by taking samples of 18 existing BPR in Denpasar City. Based on the results of the analysis found that Non Perfoming Loan has a significant negative effect on profitability, Capital Adequacy Ratio has a significant positive effect on profitability, and operational cost of operating income has a significant negative effect on profitability.

Keywords: NPL, CAR, BOPO, profitability 


\section{PENDAHULUAN}

Sesuai Undang Undang Republik Indonesia No. 7 Tahun 1992 tentang Perbankan, sebagaimana telah diubah dengan Undang-Undang No. 10 tahun 1998, Bank Perkreditan Rakyat (BPR) adalah bank yang melaksanakan kegiatan usaha secara konvensional atau berdasarkan prinsip syariah yang dalam kegiatannya tidak memberikan jasa dalam lalu lintas pembayaran.

Bank berdasarkan jenisnya, lembaga keuangan bank menurut UU No. 10 Tahun 1998 dibedakan menjadi dua, yaitu bank umum dan Bank Perkreditan Rakyat (BPR). Bank umum menurut Hendro dan Rahardja (2014:123) merupakan suatu badan usaha yang tugas utamanya sebagai perantara keuangan dengan menyalurkan dana yang berasal dari pihak yang kelebihan dana kepada pihak lain yang membutuhkan atau kekurangan dana pada waktu yang telah ditentukan, sedangkan Bank Perkreditan Rakyat (BPR) menurut Martono (2002:35) merupakan bank yang berfungsi untuk menerima simpanan dalam bentuk uang dan memberikan kredit jangka pendek bagi masyarakat di pedesaan. Bank Perkreditan Rakyat adalah salah satu bentuk lembaga keuangan mikro di Indonesia yang telah memiliki akar dalam sosial ekonomi masyarakat pedesaan Indonesia, hal ini dapat dilihat dengan telah adanya lembaga perkreditan ditengah masyarakat Indonesia seperti Lembaga Perkreditan Rakyat. Bank Perkreditan Rakyat memiliki karakter khusus seperti, memiliki berbagai bentuk pelayanan keuangan simpan dan pinjam, yang terutama ditujukan untuk melayani usaha-usaha kecil dan masyarakat di pedesaan dengan sistim serta prosedur yang sederhana dan sesuai dengan kebutuhan UMK (Upah Minimum Kota) (www.bi.go.id). 
Melihat pentingnya Bank Perkreditan Rakyat di dalam mendukung perekonomiaan masyarakat, maka keberadaan Bank Perkreditan Rakyat perlu mendapat perhatian yang lebih baik. Fungsi Bank Perkreditan Rakyat sebagai lembaga kepercayaan masyarakat tidak hanya menyalurkan kredit kepada pengusaha mikro, kecil dan menengah saja, melainkan juga menerima simpanan dari masyarakat serta memberikan persyaratan yang lebih sederhana dalam hal pemberian kredit dengan proses yang relatif cepat. Berdasarkan keunggulan tersebut, Bank Perkreditan Rakyat menjadi salah satu lembaga keuangan yang diminati oleh masyarakat dari berbagai kalangan. Peran BPR sangatlah penting untuk mendukung perekonomian masyarakat, oleh karena itu sudah seharusnya keberadaan BPR mendapatkan perhatian yang lebih baik. Kinerja keuangan BPR dapat diukur oleh masyarakat dan juga investor melalui analisis terhadap laporan keuangan. Analisis terhadap laporan keuangan suatu bank dilakukan untuk mengetahui tingkat profitabilitas dan tingkat kesehatan bank tersebut (Capriani dan Dana, 2016).

Salah satu tujuan Bank Perkreditan Rakyat adalah mengoptimalkan kegiatan operasionalnya untuk mendapatkan profitabilitas. Penting bagi bank untuk menjaga profitabilitasnya tetap stabil bahkan meningkat untuk memenuhi prudential bangking regulation dengan baik dan meningkatkan kepercayaan masyarakat untuk menyimpan kelebihan dana yang dimiliki pada bank. Ukuran profitabilitas untuk perusahaan pada umumnya dan return on assets pada perusahaan perbankan (Uthami dan Mustanda, 2016). 
Profitabilitas merupakan kemampuan bank untuk memperoleh laba dari kegiatan operasinya.Rasio profitabilitas yang digunakan adalah Return on Assets (ROA) yang merupakan rasio utama yang digunakan dalam menganalisis profitabilitas bank. Kemampuan pengelolaan bank dalam mengelola seluruh aset bank untuk menciptakan pendapatan dalam bentuk laba dihitung dengan membandingkan laba sebelum pajak dengan total aktiva (Buchory, 2014). Menurut Capriani dan Dana (2016) semakin besar ROA maka semakin besar profitabilitas yang artinya semakin baik kinerja suatu perusahaan.

Profitabilitas juga mempunyai arti penting dalam Bank Perkreditan Rakyat (BPR) yaitu untuk mempertahankan kelangsungan hidupnya dalam jangka panjang, karena profitabilitas menunjukkan apakah BPR tersebut mempunyai prospek yang baik kedepannya. Dengan demikian setiap BPR di Kota Denpasar akan selalu berusaha meningkatkan profitabilitasnya, dimana semakin tinggi profitabilitas suatu BPR maka kinerja BPR tersebut dapat dikatakan baik, karena telah beroperasi secara efektif dan efesien.

Sartono (2001:114) menyatakan rasio profitabilitas menunjukkan seberapa baiknya pengelolaan perusahaan dalam penggunaan aktiva. Pengukuran kinerja profitabilitas perusahaan pada industri perbankan umumnya diukur dengan Return On Equity (ROE) dan Return On Assets (ROA). Penelitian ini menggunakan profitabilitas yang diproksikan dengan Return On Assets (ROA) yang merupakan perbandingan laba sebelum pajak terhadap total aset, karena ROA memfokuskan kemampuan perusahaan untuk memperoleh laba dalam operasi perusahaan (Putri, 
2013). Menurut Capriani dan Dana (2016) semakin besar ROA maka semakin besar profitabilitas yang artinya semakin baik kinerja dari suatu perusahaan.

Tabel 1.

Tingkat NPL,CAR, dan BOPO pada Bank Perkrditan Rakyat di Kota Denpasar Periode Tahun 2013-2016

\begin{tabular}{ccccc}
\hline Tahun & NPL & CAR & BOPO & ROA \\
\hline 2013 & $53.72 \%$ & $21.83 \%$ & $78.05 \%$ & $4.11 \%$ \\
2014 & $3.44 \%$ & $19.61 \%$ & $75.66 \%$ & $3.88 \%$ \\
2015 & $5.05 \%$ & $20.88 \%$ & $74.05 \%$ & $4,27 \%$ \\
2016 & $8.11 \%$ & $21.11 \%$ & $82.16 \%$ & $2.83 \%$ \\
\hline
\end{tabular}

Sumber: www.bi.go.id,2017

Pada Tabel 1 dapat dilihat rasio yang terjadi pada Bank Perkreditan Rakyat di Kota Denpasar pada tahun 2013-2016 dimana NPL, CAR, BOPO, dan ROA pada empat tahun periode tersebut, tingkat NPL pada BPR di Kota Denpasar menunjukkan penurunan yang sangat tajam pada tahun 2014 yaitu dari 53.72 persen menjadi 3.14 persen, selanjutnya pada tahun 2015 kembali terjadi peningkatan sebesar 1.61 persen dan kembali peningkatan di tahun 2016 sebesar 2.06 persen sehingga menjadi 8.11 persen. Tingkat CAR menunjukan kecenderungan terjadi peningkatan kecuali pada tahun 2014 saja yang terjadi penurunan sebesar 2.2 persen. BOPO dari tahun 2014 sampai tahun 2015 terjadi penurunan dan pada tahun 2016 terjadi peningkatan sebesar 8.11 persen dari tahun sbelumnya. ROA dari tahun 2014 sampai 2015 terjadi penurunan dan pada tahun 2015 sampai 2016 juga terjadi penurunan sebesar 1.44 persen dari tahun sebelumnya.

Fenomena inilah yang mendorong peneliti untuk menggunakan Bank Perkreditan Rakyat di Kota Denpasar sebagai lokasi penelitian. Peneliti ingin mengetahui apakah ada pengaruh dari Non Perfoming Loan, Capital Adequacy 
Ratio dan Biaya Operasional Terhadap Pendapatan Operasional yang terjadi pada BPR di Kota Denpasar selama periode 2013-2016.

Profitabilitas merupakan indikator yang paling penting untuk mengukur kinerja suatu bank (Adnyani, 2011). ROA memfokuskan kemampuan perusahaan untuk memperoleh penghasilan (earning) dalam kegiatan operasi perusahaan dengan memanfaatkan aktiva yang dimiliki perusahaan. Rasio yang menunjukkan kemampuan dari keseluruhan aset yang ada dan digunakan untuk menghasilkan keuntungan. Selain itu, ROA digunakan untuk mengukur efisiensi dan efektivitas perusahaan dalam menghasilkan keuntungan dengan memanfaatkan asetnya. Sebuah perusahaan dengan tingkat profitabilitas yang tinggi menunjukkan bahwa perusahaan dapat memanfaatkan asetnya mendapatkan keuntungan lebih besaryang akan mempengaruhi pendapatan bank (Haryanto, 2016).

Non Performing Loan (NPL) yang merupakan perbandingan total kredit bermasalah dengan total kredit yang diberikan dan rasio yang digunakan untuk mengukur kemampuan bank dalam menangani kegagalan pengembalian kredit oleh debitur. NPL yang meningkat mengindikasikan kinerja perbankan semakin buruk (Capriani dan Dana, 2016). Menurut Ismail, (2014:222) kredit bermasalah akan mengakibatkan pada kerugian bank, yaitu kerugian karena tidak diterimanya kembali dana yang telah disalurkan maupun pendapatan bunga yang tidak dapat diterima.

Terdapat beberapa penelitian yang menguji pengaruh Non Perfoming Loan (NPL) terhadap profitabilitas. Menurut Wulandari dan Sudjarni (2014) NPL berpengaruh negatif pada profitabilitas. Menurut Putri dan Dewi (2017) juga 
menyatakan bahwa NPL berpengaruh negatif dan signifikan terhadap ROA. Paulin dan Wiryono et al. (2015) NPL berpengaruh negatif dan signifikan terhadap ROA.Menurut Warsa dan Mustanda (2016) NPL berpengaruh positif terhadap profitabilitas (ROA) yang dapat dilihat dari kualitas kredit, apabila NPL semakin tinggi maka profitabilitasnya (ROA) semakin rendah. Menurut Rahman et al. (2015), NPL berpemgaruh negatif signifikan terhadap profitabilitas

Capital Adequacy Ratio (CAR) mencerminkan kemampuan bank untuk menutupi risiko kerugian dari aktivitas yang dilakukannya dan kemampuan bank dalam mendanai operasionalnya (Idores, 2008:69). Modal bank sebagai salah satu kompenen yang penting bagi bank untuk menjalankan operasionalnya. Fungsi utama dari modal bank adalah sebagai sumber daya yang dapat menanggung kemungkinan atau risiko dari kerugian asset yang dimiliki. CAR di atas 8\% menunjukkan usaha bank yang stabil, karena adanya kepercayaan besar dari masyarakat (Armelia, 2011).Menurut penelitian Putri dan Dewi (2017) Capital Adequacy Ratio berpengaruh positif signifikan terhadap profitabilitas. Penelitian ini sejalan dengan penelitian yang dilakukan oleh Olaoye et al. (2015) menunjukan bahwa CAR berpengaruh positif signifikan terhadap profitabilitas. Namun, hal yang berbeda dikemukakan oleh Defri (2012) yang menunjukan bahwa CAR berpengaruh positif tidak signifikan terhadap profitabilitas, sedangkan penelitian dari Zulhelmi dan Utomo (2014) menunjukan hasil berbeda, bahwa CAR berpengaruh negatif tidak signifikan terhadap profitabilitas.

Biaya Operasional terhadap Pendapatan Operasional (BOPO) adalah rasio yang digunakan untuk mengukur perbandingan biaya operasional atau biaya 
intermediasi terhadap pendapatan operasional yang diperoleh bank. Semakin kecil angka rasio BOPO, maka semakin baik kondisi bank tersebut (Christaria dan Ratnawati, 2016). Menurut Chatarine dan Lestari (2014) Kinerja operasional merupakan kemampuan bank dalam mengatur biaya dan pendapatan operasional yang dimilikinya. Oktaviantari dan Wiagustini (2013) menyatakan bahwa bank yang memiliki tingkat BOPO yang tinggi menunjukkan bahwa bank tersebut tidak menjalankan kegiatan operasionalnya dengan efisien. Menurut Fiscal dan Lusiana (2014) hal ini sesuai dengan teori yang ada, dimana jika rasio BOPO menurun, maka seharusnya ROA mengalami kenaikan. Jika BOPO semakin kecil, maka dapat disimpulkan bahwa kinerja keuangan suatu perusahaan (perbankan) semakin meningkat atau membaik.

Haryanto (2016) menemukan bahwa BOPO berpengaruh positif dan signifikan terhadap Return On Asset (ROA). Biaya yang lebih besar dibandingkan dengan pendapatannya akan mengurangi laba yang diperoleh. Hal ini sejalan dengan peneliti Hantono at al. (2017) dan BOPO berpengaruh positif terhadap ROA. Hasil yang berbeda dilakukan oleh penelitian Prasetyo dan Darmayanti (2015), Dewi dkk. (2015), Capriani dan Dana (2016) menunjukkan BOPO memiliki pengaruh negatif dan signifikan terhadap profitabilitas.

Menurut Sartono (2010:122) profitabilitas adalah kemampuan bank memperoleh laba dalam hubungan dengan penjualan, total aktiva maupun modal sendiri. Rasio profitabilitas merupakan rasio untuk menilai kemampuan bank dalam mencari keuntungan. Rasio ini juga memberikan ukuran efektivitas manajemen suatu bank. Penggunaan rasio profitabilitas dapat dilakukan dengan perbandingan 
antara berbagi kompenen yang ada di laporan keuangan, tujuannya adalah agar dapat terlihat perkembangan suatu bank dalam rentang waktu tertentu, baik penurunan atau kenaikan, sekaligus mencari penyebab perubahan tersebut (Kasmir, 2011).

Penelitian ini menggunakan ROA untuk memproksikan profitabilitasnya karena ROA lebih fokus untuk menghitung kemampuan perbankan dalam mengelola aktiva yang dimilikinya agar dapat menghasilkan keuntungan. Menurut Prasetyo dan Darmayanti (2015), ROA merupakan proksi dari profitabilitas yang paling penting di dalam perbankan dibanding proksi profitabilitas lainnya. Tingginya tingkat ROA pada suatu bank menunjukkan bahwa tingkat return yang diterima oleh bank tersebut juga tinggi. Perekonomian yang memiliki sektor perbankan dengan tingkat profitabilitas yang tinggi akan lebih mampu berkontribusi pada stabilitas sistem keuangan. ROA memberikan ukuran yang lebih baik atas profitabilitas perusahaan karena menjukan efektivitas manajemen dalam menggunakan aktiva untuk memperoleh pendapatan (Fahmi, 2012:98).

Menurut Sartono (2001:114) rasio profitabilitas menunjukkan seberapa baiknya pengelolaan perusahaan dalam penggunaan aktiva. Penelitian ini menggunakan profitabilitas yang diproksikan dengan Return On Assets (ROA) yang merupakan perbandingan laba sebelum pajak terhadap total aset, karena ROA memfokuskan kemampuan bank untuk memperoleh laba (Putri, 2013).

Kelancaran debitur dalam membayar kewajibannya, yaitu pokok angsuran dan bunga adalah sebuah keharusan, karena bank merupakan lembaga intermediasi perbankan yang tugasnya menampung dan menyalurkan dana dari bank ke 
masyarakat, sehingga pembayaran kredit oleh debitur merupakan sebuah keharusan agar kegiatan operasionalnya bank tetap dapat berjalan dengan lancar. Tingkat kesehatan bank merupakan hal yang penting yang harus diusahakan oleh manajemen bank. (Butar-butar, 2008).

Riyadi (2006:160) mengatakan Non Performing Loan adalah perbandingan antara jumlah kredit yang diberikan dengan tingkat kolektibilitas 3 sampai 5 dibandingkan dengan total kredit yang diberikan oleh bank. Semakin besar tingkat NPL menunjukkan bahwa bank tersebut tidak profesional dalam pengelolaan kreditnya, jadi semakin tinggi rasio ini maka akan semakin buruk kualitas kredit bank yang menyebabkan jumlah kredit bermasalah semakin besar dan menyebabkan kerugian, sebaliknya jika semakin rendah NPL maka laba atau profitabilitas bank tersebut akan semakin meningkat (Riyadi, 2006:161).

Rasio NPL digunakan untuk mengukur kemampuan manajemen bank dalam mengelola kredit bermasalah yang diberikan oleh bank. Semakin tinggi rasio ini maka akan semakin buruk kualitas kredit bank yang menyebabkan jumlah kredit bermasalah semakin besar dan menyebabkan kerugian, sebaliknya jika semakin rendah NPL maka laba atau profitabilitas bank tersebut akan semakin meningkat (Herawati dan Sulindawati, 2015). Hal tersebut tentu saja akan mempengaruhi pertumbuhan modal bank. Selain besarnya beban operasional dan meningkatnya NPL yang dapat mempengaruhi pertumbuhan modal, terdapat faktor lain yang mempengaruhi jumlah modal yaitu pembagian deviden yang tidak seimbang dengan laba ditahan karena modal bersih bank mencerminkan jumlah dana yang akan disalurkan kembali kepada masyarakat (Budiawan, 2008). 
Capital Adequacy Ratio (CAR) merupakan perbandingan antara modal sendiri dengan asset tertimbang menurut risiko. Pengelolaan modal yang baik akan membantu memperlancar aktivitas utama bank yaitu dalam pemberian kredit. modal juga dapat mempengaruhi kepercayaan masyarakat, apabila tingkat modal bank yang ideal maka hal tersebut akan meningkatkan kepercayaan masyarakat dalam menginvestasikan dananya (Ariwidanta, 2016).

Capital Adequacy Ratio adalah rasio kinerja bank untuk mengukur kecukupan modal yang dimiliki bank untuk menunjang aktiva. CAR merupakan indikator terhadap kemampuan bank untuk menutupi penurunan aktivanya sebagai akibat dari kerugian-kerugian bank yang disebabkan oleh aktiva yang berisiko (Eng, 2013:158). Menurut Prasanjaya dan Ramantha (2013) bank dengan modal yang tinggi dianggap relatif lebih aman dibandingkan dengan bank modal yang rendah, hal ini disebabkan bank dengan modal yang tinggi biasanya memiliki kebutuhan yang lebih rendah dari pada pendanaan eksternal. Bank Indonesia menetapkan besarnya rasio CAR yaitu minimum 8 persen.

Modal terdiri dari jumlah modal inti dan modal pelengkap, sedangkan Aktiva Tertimbang Menurut Risiko (ATMR) adalah nilai total masing-masing aktiva bank setelah dikalikan dengan masing masing bobot risiko aktiva tertimbang tersebut.

BOPO adalah rasio biaya operasi dibandingkan pendapatan operasi. Bank yang memiliki tingkat BOPO yang tinggi menunjukkan bahwa bank tersebut tidak menjalankan kegiatan operasionalnya dengan efisien. Rasio BOPO digunakan untuk mengukur tingkat efisiensi dan kemampuan bank dalam melakukan kegiatan operasinya. Rasio BOPO juga digunakan untuk mengatur kemampuan manajemen 
bank dalam mengendalikan biaya operasional dan pendapatan operasional. Apabila semakin kecil rasio BOPO maka akan semakin efisien biaya operasional yang dikeluarkan bank. Berdasarkan ketentuan Bank Indonesia, bank dapat dikatakan efisien apabila rasio BOPOnya dibawah 90\% (Susanto dan Kholis, 2016:14). Menurut Veithzal (2013:131) menjelaskan bahwa pengertian BOPO adalah biaya operasional pendapatan operasional adalah rasio yang digunakan untuk mengukur tingkat efisiensi dan kemampuan bank dalam melakukan kegiatan operasinya. Rasio ini sering juga disebut sebagai rasio efisiensi yang digunakan untuk mengukur kemampuan manajemen bank dalam mengendalikan biaya operasional terhadap pendapatan operasional. Semakin kecil rasio ini berarti semakin efisien biaya operasional yang dikeluarkan bank yang bersangkutan sehingga kemungkinan suatu bank ada dalam kondisi bermasalah semakin kecil. Rasio BOPO menunjukkan adanya risiko operasional yang ditanggung bank (Pamularsih, 2015).

Menurut Riyadi (2006:159) BOPO adalah rasio antara biaya operasinal dibandingkan pendapatan operasional. Semakin tinggi tingkat BOPO suatu bank maka semakin tidak efisien biaya operasional yang dikeluarkan. Peningkatan biaya operasional dari suatu bank akan menurunkan laba atau profitabilitas yang akan didapat oleh bank tersebut (Capriani dan Dana, 2016).

Non Perfoming Loan merupakan krdit yang sedang mengalami kemacetan dalam pelunasannya yang terjadi karena faktor internal maupun eksternal, sehingga dapat mengurangi perolehan laba dan berpengaruh buruk bagi profitabilitas bank. Pada penjelasan tersebut dapat di lihat bahwa kredit bermasalah dapat 
memengaruhi kemampuan untuk mengelola keuntungan bank artinya profitabilitas akan tergantung pada besar kecilnya kredit bermasalah yang dihadapai oleh pihak bank (Putri dan Suhermin, 2015).

NPL merupakan rasio yang menunjukkan kemampuan manajemen bank dalam mengelola kredit bermasalah. Semakin tinggi rasio NPL, maka semakin buruk kualitas kredit yang menyebabkan jumlah kredit bermasalah semakin besar sehingga dapat menyebabkan kemungkinan suatu bank dalam kerugian. Penyebab kredit macet biasanya disebabkan oleh kurangnya pemantauan dan pengawasan yang efektif di pihak bank (Bhattarai, 2016). Menurut Putri dan Suhermin (2015) salah satu munculnya kredit bermasalahmengakibatkan semakin kompleksnya kegiatan perbankan. Non Perfoming Loan (NPL) yang semakin tinggi rasio ini maka akan semakin buruk kualitas kredit bank yang menyebabkan jumlah kredit bermasalah semakin besar. Menurut SE BI Nomor 13/24/DPNP tanggal 25 Oktober 2011 standar NPL yang sehat jika jumlah kredit bermasalah tidak lebih dari 5\% dari total kredit yang diberikan kepada debitur.

Berdasarkan Peraturan Bank Indonesia Nomor 18/14PBI/2016 Bank Indonesia menetapkan bahwa NPL yang wajar adalah 5\%. Terdapat beberapa penelitian yang menguji pengaruh Non Perfoming Loan (NPL) terhadap profitabilitas. Menurut Wulandari dan Sudjarni (2014) NPL berpengaruh negatif terhadap profitabilitas. Menurut Putrid dan Dewi (2017) juga menyatakan adanya pengaruh negatif dansignifikan terhadap profitabilitas. Berdasarkan uraian tersebut dapat ditarik hipotesis sebagai berikut :

$\mathrm{H}_{1}$ : Non Perfoming Loan memiliki perngaruh negatif signifikan terhadap profitabilitas. 
Permodalan bagi bank sebagaimana perusahaan pada umumnya selain berfungsi sebagai sumber utama pembiayaan terhadap kegiatan operasionalnya juga berperan sebagai penyangga terhadap kemungkinan terjadinya kerugian (Fiscal dan Lusiana, 2014). Menurut Defri dan Hamka (2012) bank yang tidak memiliki kecukupan modal maka bank tersebut bisa dikatakan tidak sehat rasionya, sehingga bank tersebut masuk dalam kriteria bank dalam pengawasan khusus karena rasio kecukupan modal CAR-nya di bawah standar yang ditetapkan Bank Indonesia (8\%). Jika nilai CAR rendah maka profitabilitas (ROA) bank akan mengalami penurunan.

Hasil dari penelitian yang telah dilakukan oleh Putridan Dewi (2017) Capital Adequacy Ratio berpengaruh positif signifikan terhadap profitabilitas sedangkan penelitian dari Ningrum (2016) berpengaruh positif dan signifikan terhadap profitabilitas. Pendapat ini sejalan dengan Defri (2012), Septiani dan Lestari (2016) Capital Adequacy Ratio (CAR) berpengaruh positif dan signifikan terhadap profitabilitas Berdasarkan uraian tersebut dapat ditarik hipotesis sebagai berikut :

$\mathrm{H}_{2}$ : Capital Adequacy Ratiomemiliki pengaruh positif signifikan terhadap profitabilitas

Bank yang memiliki tingkat BOPO yang tinggi menunjukkan bahwa bank tersebut tidak menjalankan kegiatan operasionalnya dengan efisien sehingga memungkinkan risiko operasional yang dimiliki oleh bank akan semakin besar (Oktaviantari dan Wiagustini, 2013). Tingginya rasio BOPO menunjukkan bahwa bank tidak dapat mengelola sumber dana dan aktiva yang dimiliki untuk memperoleh laba. Tingginya rasio BOPO tersebut dapat mengikis modal bank sehingga dapat mengganggu kesehatan bank (Chatarine dan Lestari, 2014). 
Menurut Dewi dkk. (2015) mengingat kegiatan utama bank pada prinsipnya adalah bertindak sebagai perantara, yaitu menghimpun dan menyalurkan dana masyarakat, maka biaya dan pendapatan operasional bank didominasi oleh biaya bunga dan hasil bunga. Setiap peningkatan biaya operasional akan berakibat pada berkurangnya laba sebelum pajak yang pada akhirnya akan menurunkan laba atau profitabilitas bank yang bersangkutan.

Berdasarkan ketentuan Bank Indonesia, bank dapat dikatakan efisien apabila rasio BOPOnya dibawah 90\%. Bank yang sehat ketentuan dari BI harus memiliki BOPO $\leq 93,52$ persen (Surat Edaran Bank Indonesia No.6/23/DPNP tanggal 31 Mei 2004). Sebuah bank memiliki BOPO lebih dari ketentuan BI maka bank tersebut kategori tidak sehat dan tidak efisien (Capriani dan Dana, 2016).

Hasil penelitian yang dilakukan oleh Santoso (2016) yang menunjukkan biaya operasional memiliki pengaruh negatif terhadap profitabilitas yang sejalan dengan penelitian dari Capriani dan Dana (2016), Putri dan Dewi (2017) berdasarkan uraian tersebut dapat ditarik hipotesis sebagai berikut:

$\mathrm{H}_{3}$ : Biaya Operasional pendapatan operasonal memiliki pengaruh negatif signifikan terhadap profitabilitas

\section{METODE PENELITIAN}

Lokasi penelitian dilakukan di seluruh Bank Perkreditan Rakyat (BPR) Kota Denpasar dengan mengambil data laporan keuangan pertahun Bank Perkreditan Rakyat (BPR) yang dipublikasikan di Bank Indonesia. Alasan penelitian ini mengambil lokasi di Kota Denpasar adalah karena Kota Denpasar merupakan salah satu wilayah di Bali dengan jumlah BPR yang paling banyak sehingga diharapkan 
nantinya dapat memberikan gambaran yang lebih luas mengenai karakteristik data yang diteliti.

Populasi yang digunakan pada penelitian ini adalah Bank Perkreditan Rakyat di Kota Denpasar pada periode 2013-2016. Penelitian ini menggunakan penentuan sampel yaitu sampel jenuh. Menurut Sugiyono (2016:96), sampel jenuh merupakan teknik penentuan sampel bila semua anggota populasi dari suatu penelitian digunakan sebagai sampel. Dalam penelitian ini adalah seluruh Bank Perkreditan Rakyat di Kota Denpasar pada periode 2013-2016 yaitu sebanyak 18 Bank Perkreditan Rakyat.

Metode pengumpulan data yang digunakan dalam penelitian ini adalah metode observasi non participant. Penelitian ini, peneliti melakukan pengamatan pada data yang bersumber dari buku serta laporan keuangan BPR di Kota Denpasar pada periode 2013-2016 yang diperoleh dari website Bank Indonesia (www.bi.go.id)

Analisis regresi linier berganda digunakan untuk mengetahui besarnya pengaruh Non Permofing Loan, Capital Adequacy Ratio dan Biaya Operasional Pendapatan Operasional terhadap profitabilitas pada Bank Perkreditan Rakyat periode 2013-2016. Adapun persamaan regresi linier berganda dirumuskan secara sistematis sebagai berikut (Ghozali, 2011:97):

$\mathrm{Y}=\alpha+\beta_{1} X_{1}+\beta_{2} X_{2}+\beta_{3} X_{3}+\mathrm{e}$

Keterangan:

$\mathrm{Y}=$ Profitabilitas $(R O A)$

$\alpha \quad=$ Konstanta

$\beta_{1} \quad=$ Koefisien regresi dari Non Perfoming Loan $\left(X_{1}\right)$

$\beta_{2} \quad=$ Koefisien regresi dari Capital Adequency Ratio $\left(X_{2}\right)$ 


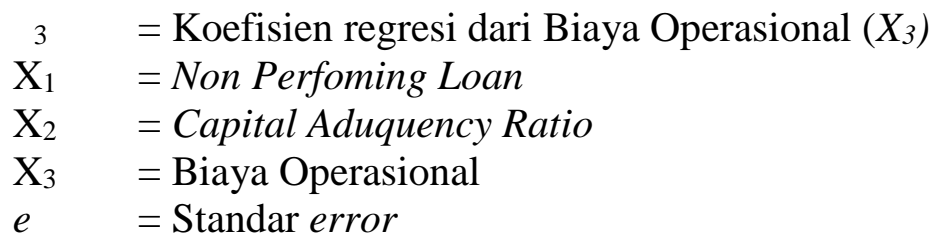

\section{HASIL PENELITIAN DAN PEMBAHASAN}

Analisis dan deskritif dilakukan untuk memberikan gambaran atau deskripsi mengenai variabel yang diteliti dimana terdiri dari Non Perfoming Loan $\left(\mathrm{X}_{1}\right)$, Capital Adequacy Ratio $\left(\mathrm{X}_{2}\right)$, Biaya Operasional Pendapatan Operasional $\left(\mathrm{X}_{3}\right)$ dan profitabilitas (Y) yang terlihat pada Tabel 2.

Tabel 2.

Statistik Deskriptif Sampel Penelitian

\begin{tabular}{lccccc}
\hline & N & Minimum & Maximum & Mean & $\begin{array}{c}\text { Std. } \\
\text { Deviation }\end{array}$ \\
\hline NPL & 72 & 0 & 18 & 4.8333 & 4.64819 \\
CAR & 72 & 9 & 40 & 21.000 & 6.90580 \\
BOPO & 72 & 46 & 153 & 81.0417 & 14.39331 \\
ROA & 72 & 0 & 12 & 3.7778 & 2.44501 \\
Valid N & 72 & & & & \\
(listwise) & & & & & \\
Sumber: Data diolah, 2018 & &
\end{tabular}

Tabel 2 memperlihatkan hasil uji statistik masing-masing variabel bahwa Non Perfoming Loan adalah untuk mengukur kemampuan manajemen bank dalam mengelola kredit bermasalah. Kredit bermasalah yang terjadi apabila nasabah tidak dapat mengembalikan pinjaman dari BPR Kota Denpasar sesuai jangka waktu yang telah ditentukan. Penelitian ini memproksikan dengan menggunakan NPL (Non Perfoming Loan). Berdasarkan Tabel 2 dapat dilihat bahwa rata-rata NPL di BPR Kota Denpasar sebesar 4,8333 persen dengan nilai NPL tertinggi sebesar 18 persen yang terjadi pada tahun 2016 dan nilai NPL terendah yang terjadi pada tahun 2013 sampai 2015 yaitu sebesar 0 persen. 
Capital Adequacy Ratio adalah menyalurkan modal yang dimiliki bank untuk menunjang aktiva dan kemampuan bank untuk mendapatkan keuntungan dalam mengelola asetnya serta menanggung beban dari aktivitas operasi bank.Penelitian ini memproksikan dengan menggunakan CAR (Capital Adequacy Ratio). Berdasarkan Tabel 2 dapat dilihat bahwa rata-rata CAR di BPR Kota Denpasar sebesar 21,000 persen dengan nilai CAR tertinggi sebesar 40 persen pada tahun 2014 dan nilai CAR terendah sebesar 9 persen yang terjadi pada tahun 2014 .

Biaya Operasional Pendapatan Operasional adalah untuk mengukur kemampuan bank dalam melakukan kegiatan operasional denganmenggunakan biaya operasional dan pendapatan operasional. Penelitian ini memproksikan dengan menggunakan Biaya Operasional Pendpatan Operasional (BOPO). Berdasarkan Tabel 2 dapat dilihat bahwa rata-rata BOPO di BPR Kota Denpasar sebesar 81,0417 persen dengan nilai BOPO tertinggi sebesar 153 persen pada tahun 2016 dan nilai BOPO terendah sebesar 46 persen yang terjadi pada tahun 2015.

Profitabilitas merupakan kemampuan memperoleh laba atau profit merupakan salah satu untuk memberikan ukuran efektivitas manajemen suatu bank dan digunakan untuk menghasilkan keuntungan. Penelitian ini memproksikan dengan menggunakan ROA (Return on Assets) untuk mewakili tingkat profitabilitas. Berdasarkan Tabel 2., dapat dilihat bahwa rata-rata ROA di BPR Kota Denpasar sebesar 3,7778 persen dengan nilai ROA tertinggi terjadi pada tahun 2014 dan 2015 yaitu sebesar 12 persen dan nilai ROA terendah sebesar 0 persen terjadi pada tahun 2013 sampai 2016. 
Analisis regresi linier berganda digunakan untuk mengetahui besarnya pengaruh dan signifikansi Non Perfoming Loan, Capital Adequacy Ratio dan Biaya Operasional Pendapatan Operasional terhadap profitabilitas BPR di Kota Denpasar pada tahun 2013-2016. Hasil perhitungan regresi linier berganda dihitung menggunakan bantuan SPSS.

Tabel 3.

Uji Analisis Regresi Linier Berganda

\begin{tabular}{|c|c|c|c|c|c|}
\hline \multirow{2}{*}{ Model } & \multicolumn{2}{|c|}{$\begin{array}{c}\text { Unstandardized } \\
\text { Coefficients }\end{array}$} & \multirow{2}{*}{$\begin{array}{c}\text { Standardized } \\
\text { Coefficients } \\
\text { Beta }\end{array}$} & \multirow{2}{*}{$T$} & \multirow{2}{*}{ Sig. } \\
\hline & B & $\begin{array}{c}\text { Std. } \\
\text { Error }\end{array}$ & & & \\
\hline (Constant) & 11,295 & 1,548 & & 7,295 & 0,000 \\
\hline NPL & $-0,092$ & 0,045 & $-0,175$ & $-2,039$ & 0,045 \\
\hline CAR & 0,062 & 0,031 & 0,175 & 2,011 & 0,048 \\
\hline BOPO & $-0,103$ & 0,015 & $-0,608$ & $-6,719$ & 0,000 \\
\hline $\mathrm{R}$ & 0,746 & & & & \\
\hline $\mathrm{R}^{2}$ & 0,556 & & & & \\
\hline Adjusted $\mathrm{R}^{2}$ & 0,537 & & & & \\
\hline F hitung & 28,412 & & & & \\
\hline Sig. F & 0,000 & & & & \\
\hline
\end{tabular}

Berdasarkan Tabel 3. dapat diperoleh persamaan regresi linier berganda sebagai berikut:

$$
\mathrm{Y}=11,295-0,092 \mathrm{X} 1+0,062 \mathrm{X}_{2}-0,103 \mathrm{X}_{3}
$$

Keterangan :

$\mathrm{Y}=$ Profitabilitas $(R O A)$

$\alpha=$ Konstanta

$\beta_{1}=$ Koefisien regresi dari Risiko Likuiditas $\left(X_{1}\right)$

$\beta_{2}=$ Koefisien regresi dari Risiko Kredit $\left(X_{2}\right)$

$\beta_{3}=$ Koefisien regresi dari Risiko Operasional $\left(X_{3}\right)$

$\mathrm{X}_{1}=$ Risiko Likuiditas

$\mathrm{X}_{2}=$ Risiko Kredit

$\mathrm{X}_{3}=$ Risiko Operasional

$e=$ Standar error 
Berdasarkan persamaan tersebut, maka dapat dijelaskan arti dari masingmasing koefisien adalah Konstanta (Y): 11,295 artinya apabila variabel NPL, CAR dan BOPO sama dengan nol, maka besarnya variabel dependen profitabilitas (Y) sebesar 11,295.

Koefisien (X1) : -0,092 artinya apabila NPL naik sebesar 1 persen, sementara variabel independen lainnya konstan maka profitabilitas akan mengalami pnenurunan sebesar -0,092.

Koefisien (X2) :0,062 artinya apabila CAR naik sebesar 1 persen, sementara variabel independen lainnya konstan maka profitabilitas akan mengalami peningkatan sebesar 0,062 .

Koefisien (X3) :-0,103 artinya apabila BOPO naik sebesar 1 persen, sementara variabel independen lainnya konstan maka profitabilitas akan mengalami penurunan sebesar $-0,103$.

Uji t dilakukan untuk mengetahui apakah Non Perfoming Loan, Capital Adequacy Ratio dan Biaya Operasional Pendapatan Operasional berpengaruh secara signifikan terhadap profitabilitas.

Tabel 4.

Hasil Uji Statistik t (Parsial)

\begin{tabular}{|c|c|c|c|c|c|c|}
\hline \multirow{2}{*}{ Model } & & \multicolumn{2}{|c|}{$\begin{array}{c}\text { Unstandardized } \\
\text { Coefficients }\end{array}$} & \multirow[t]{2}{*}{$\begin{array}{c}\text { Standardized } \\
\text { Coefficients }\end{array}$} & \multirow{2}{*}{$T$} & \multirow{2}{*}{ Sig. } \\
\hline & & $\boldsymbol{B}$ & $\begin{array}{c}\text { Std. } \\
\text { Error }\end{array}$ & & & \\
\hline \multirow{4}{*}{1} & (Constant) & 11,295 & 1,548 & & 7,295 &, 000 \\
\hline & NPL &,- 092 & 0,045 &,- 175 & $-2,039$ &, 045 \\
\hline & CAR & ,062 & 0,031 &, 175 & 2,011 & ,048 \\
\hline & BOPO &,- 103 & 0,015 &,- 608 & $-6,719$ &, 000 \\
\hline
\end{tabular}


Ni Kadek Alit Pradina Putri, Pengaruh.....

Berdasarkan Tabel 4 dapat dilihat bahwa variabel NPL memiliki nilai t hitung yang lebih besar dari $\mathrm{t}$ tabel $(-2,039<1,995)$ dengan nilai signifikansi 0,045 yang lebih kecil dari 0,05. Hasil ini menunjukan bahwa NPLberpengaruh negatif dan signifikan terhadap profitabilitas yang diwakili oleh ROA. Hasil penelitian ini didukung oleh penelitian sebelumnya yang dilakukan oleh Wulandari dan Sudjarni, (2014) NPL berpengaruh negatif terhadap profitabilitas. Menurut Putri dan Dewi (2017) juga menyatakan adanya pengaruh negatif dansignifikan terhadap profitabilitas. Menurut Paulin dan Wiryono et al. (2015) NPL berpengaruh negatif dan signifikan terhadap profitabilitas. Menurut Rahman et al. (2015) berpengaruh negatif signifikan terhadap profitabilitas.

Berdasarkan Tabel 4 dapat dilihat bahwa variabel CAR memiliki nilai t hitung yang lebih kecil dari t tabel $(2,011>1,995)$ dengan nilai signifikansi sebesar 0,048 yang lebih kecil dari 0,05. Hasil ini menunjukkan CAR berpengaruh positif dan signifikan terhadap profitabilitas yang diwakili oleh ROA. Hasil penelitian ini didukung oleh penelitian sebelumnya yang dilakukan oleh Putri dan Dewi (2017) Capital Adequacy Ratio berpengaruh positif signifikan terhadap profitabilitas sedangkan penelitian dari Ningrum (2016) berpengaruh positif dan signifikan terhadap profitabilitas. Menurut Olaoye et al. (2015) berpangurh positif terhadap profitabilitas.

Berdasarkan Tabel 4 dapat dilihat bahwa variabel BOPO memiliki nilai t hitung yang lebih kecil dari t tabel $(-6,719<1,995)$ dengan nilai signifikansi 0,000 yang lebih kecil dari 0,05. Hasil ini menunjukkan bahwa BOPO berpengaruh negatif dan signifikan terhadap profitabilitas yang diwakili oleh ROA. Hasil penelitian ini sejalan dengan penelitian sebelumnya yaitu penelitian yang dilakukan 
Santoso (2016) yang menunjukkan biaya operasional memiliki pengaruh negatif terhadap profitabilitas yang sejalan dengan penelitian dari Capriani dan Dana (2016), Putri dan Dewi (2017), Christaria dan Kurnia et al. (2016) BOPO berpengaruh negatif signifikan terhadap profitabilitas.

Penelitian ini menggunakan Uji kelayakan model atau yang biasa disebut uji F adalah uji statistik yang dilakukan untuk mengetahui apakah variabel Non Perfoming Loan, Capital Adequacy Ratio dan Biaya Operasional Pendapatan Operasional mempunyai pengaruh secara bersama-sama terhadap profitabilitas.

Tabel 5.

Hasil Uji F (Simultan)

\begin{tabular}{ccccccc}
\hline \multicolumn{1}{l}{ Model } & $\begin{array}{c}\text { Sum of } \\
\text { Squares }\end{array}$ & Df & $\begin{array}{c}\text { Mean } \\
\text { Square }\end{array}$ & $\boldsymbol{F}$ & Sig. \\
\hline \multirow{4}{*}{1} & Regression & 236,094 & 3 & 78,689 & 28,412 &, 000 \\
& Residual & 188,350 & 68 & 2,770 & & \\
& Total & 424,444 & 71 & & & \\
\hline
\end{tabular}

Sumber: Data diolah, 2018

Tabel 5 menunjukkan, berdasarkan hasil uji nilai signifikansi $\mathrm{F}$ adalah sebesar 0,000 yang lebih kecil dari 0,05 $(\mathrm{F}<\alpha)$ yang berarti variabel Non Perfoming Loan, Capital Adequacy Ratio dan Biaya Operasional Pendapatan Operasional mempunyai pengaruh secara bersama-sama terhadap profitabilitas.sehingga penelitian ini dapat dikatakan memenuhi uji kelayakan model atau model penelitian dinyatakan layak digunakan sebagai model regresi.

Koefisien determinasi merupakan alat untuk mengukur kemampuan model yang akan menunjukkan persentase variasi variabel terikatnya. Besarnya nilai koefisien determinasi $\left(\mathrm{R}^{2}\right)$ dilihat pada tabel 6 di bawah ini : 
Tabel 6.

Koefisien Determinasi

\begin{tabular}{ccccc} 
Model & $\boldsymbol{R}$ & $\boldsymbol{R}$ Square & $\begin{array}{c}\text { Adjusted } \boldsymbol{R} \\
\text { Square }\end{array}$ & $\begin{array}{c}\text { Std. Error of the } \\
\text { Estimate }\end{array}$ \\
\hline 1 &, 746 &, 556 &, 537 & 1,66429 \\
\hline
\end{tabular}

Sumber: Data diolah, 2018

Besarnya nilai adjusted $\mathrm{R}$ square adalah sebesar 0,537 yang artinya sebesar 53,7 persen variasi profitabilitas dipengaruhi oleh Non Perfoming Loan, Capital Adequacy Ratio dan Biaya Operasional Pendapatan Operasional, sedangkan sisanya sebesar 46,3 persen dipengaruhi oleh faktor-faktor lain yang tidak dimasukkan kedalam model penelitian.

\section{SIMPULAN DAN SARAN}

Berdasarkan uraian sebelumnya maka dapat disimpulkan bahwa Non Perfoming Loan berpengaruh negatif dan signifikan terhadap profitabilitas. Hal ini menunjukkan apabila tingkat Non Perfoming Loan BPR di Kota Denpasar tinggi, menunjukkan bahwa semakin buruk kualitas kredit yang akan menyebabkan terjadinya kredit macet dantingginya kredit macet yang terjadi bank tersebut menyebabkan pendapatan yang diterima oleh bank akan menurun.

Capital Adequacy Ratio berpengaruh postif dan signifikan terhadap profitabilitas. Hal ini menunjukkan apabila Capital Adequacy Ratiopada BPR di Kota Denpasar meningkat maka profitabilitas yang didapatkannya akan semakin meningkat. 
Biaya operasional pendapatan operasional berpengaruh negatif signifikan terhadap profitabilitas. Hal ini menunjukkan bahwa apabila biaya operasional BPR di Kota Denpasar meningkat maka profitabilitas yang didapatkan akan menurun.

Berdasarkan kesimpulan yang telah diuraikan maka saran yang dapat diberikan Bagi Pihak BPR Non Perfoming Loan berpengaruh negatif dan signifikan terhadap profitabilitas yang diwakili oleh ROA, maka disarankan kepada pihak BPR di Kota Denpasar melaksanakan analisis kredit yang lebih tepat dalam menyalurkan kredit, sehingga mengurangi kredit yang bermasalah atau macet dan dapat menurunkan NPL, selanjutnya meningkatkan profitabilitas, karena penemuan penelitian NPL pengaruh negatif terhadap profitabilitas. Capital Adequacy Ratio berpengaruh positif dan signifikan terhadap profitabilitas yang diwakili ROA, maka disarankan kepada pihak BPR agar lebih banyak menyalurkan kredit untuk meningkatkan profitabilitasnya. Biaya operasional pendapatan operasional berpengaruh negatif dan signifikan terhadap profitabilitas yang diwakili ROA, maka disarankan kepada pihak BPR di Kota Denpasar agar lebih menekan biaya operasionalnya untuk mendapatkan kentungan yang lebih besar.

Bagi peneliti selanjutnya yaitu penelitian ini memiliki keterbatasan hanya menggunakan NPL,CAR dan BOPO sebagai determinasi profitabilitas BPR, untuk peneliti selanjutnya disarankan menggunakan atau menambahkan variabel lain seperti Likuiditas, Dana pihak ketiga, dan lain-lain sebagai determinasi profitabilitas BPR. 


\section{REFERENSI}

Ariwidanta, Komang Triska. 2016. Pengaruh Risiko Kredit Terhadap Profitabilitas Dengan Kecukupan Modal Sebagai Variabel Mediasi. E-Jurnal Manajemen Unud, 5 (4), hal. 2311-2340.

Bhattarai, Dr. Yuga Raj.2016. Effect of Non-Performing Loan on the Profitability of Commercial Banks in Nepal. The International Journal Of Business \& Management, Vol 10, Iss. 2, pp. 1-9

Capriani, Ni Wayan Wita dan Dana, I Made. 2016. Pengaruh Risiko Kredit Risiko Operasional dan Risiko Likuiditas Terhadap Profitabilitas BPR di Kota Denpasar. E-Jurnal Manajemen Unud, 5 (3), hal.1486-1512.

Chatarine,Alvita dan Lestari, Putu Vivi. 2014. Pengaruh Kualitas Aktiva Produktif, BOPO Terhadap ROA dan CAR Pada BPR Kabupaten Badung, E-Jurnal Manajemen Unud, 3 (3), hal. 567-577.

Defri. 2012. Pengaruh Capital Adequacy Ratio (CAR), Likuiditas Dan Efisiensi Operasionalterhadap Profitabilitas Perusahaan Perbankan Yang Terdaftar Di BEI, Jurnal Manajemen, 1 (1). Hlm 1-18

Dewi, Luh Eprima dkk. 2015. Analisis Pengaruh NIM, BOPO, LDR, dan NPL Terhadap Profitabilitas (Studi Kasus Pada Bank Umum Swasta Nasional Yang Terdaftar Pada Bursa Efek Indonesia Periode 2009-2013 ), E-Journal S1 Ak. Universitas Pendidikan Ganesha Jurusan Akuntansi Program S1, 3 (1), hlm 1-11

Fiscal, Yunus dan Lusiana, Lili. 2014. Pengaruh Capital Adequacy Ratio (CAR), Loan To Deposit Ratio (LDR), Biaya Operasional Dan Pendapatan Operasional (Bopo) Terhadap Profitabilitas BPR ( Studi Kasus pada BPR di Provinsi Lampung Tahun 2010 - 2012 ), Jurnal Akuntansi \& Keuangan, 5 (2), hal. 127-158.

Fahmi, Irfan. 2012. Analisis Laporan Keuangan. Cetakan ke-2 Penerbit : Alfabeta Bandung.

Ghozali, Imam. 2011. Aplikasi Analisis Multivariate dengan Program SPSS. Semarang : Badan Penerbit Universitas Diponegoro.

Gunawan, Imam. 2016. Pengantar Statistika Inferensial. Jakarta: Rajawali Pers. 
Hantono. 2017. Effect Of Capital Adequacy Ratio (CAR), Loan To Deposit Ratio (LDR) And Non Performing Loan (NPL) To Return On Assets (ROA) Listed In Banking In Indonesia Stock Exchange, International Journal of Education and Research, Vol. 5, No. 2, pp 69-80

Haryanto, Sugeng. 2016. Profitability Identification Of National Banking Through Credit, Capital, Capital Structure, Efficiency, And Risk Level, Finance and Banking D-III Program, Merdeka Malang University, Malang, Indonesia. 7, No. 1 pp. 11-21.

Ismail. 2004. Teori dan Apliksi dalam Rupiah. Edisi Revisi. Jakarta : Kencana Prenadamedia Group.

Kasmir.2015. Bank dan Lembaga Keuangan lainnya. Edisi Revisi 2014.Jakarta :Rajawali Pers.

Martono, 2002. Bank dan Lembaga Keuangan Lain. Yogyakarta Ekonisia.

Malimi, Kilugala. 2017. The Influence of Capital Adequacy, Profitability, and Loan Growth on Non- Performing Loans a Case of Tanzanian Banking Sector. International Journal of Economics, Business and Management Studies, 4 (1), pp. 38-49.

Ningrum, Putu Rubyana Charoline. 2016. Pengaruh CAR dan LDR Terhadap Profitabilitas Pada PT.BPR MBM Di Badung Tahun 2013-2015, Jurnal Program Studi Pendidikan Ekonomi, 8 (3), hlm. 1-10

Oktaviantari, Luh Putu Eka dan Wiagustini, Ni Luh Putu. 2013. Pengaruh Tingkat Risiko Perbankan Terhadap Profitabilitas Pada BPR Di Kabupaten Badung. E-Jurnal Manajemen Universitas Udayana, 2 (12), hal. 1617-1633.

Olaoye,Festus Oladipupo Olarewaju, Odunayo M, 2015. Determinants Of Deposit Money Banks Profitability In Nigeria. Kuwait Bab Arabian Jurnal Bisnis dan Manajemen Ulasan, 4 (9), pp. 11-15

Prasanjaya, A.A. Yogi dan Ramantha, I Wayan. 2013. Analisis Pengaruh Rasio CAR, BOPO, LDR Dan Ukuran Perusahaan Terhadap Profitabilitas Bank Yang Terdaftar Di BEI. E-Jurnal Akuntansi Universitas Udayana, 4 (1), hal. 230-245.

Putri ,Rosana Nur Oktavia Subagiono dan Dewi, Sayu Kt. Sutrisna. 2017.Pengaruh LDR, CAR, NPL, BOPO Terhadap Profitabilitas Lembaga Perkreditan 
Ni Kadek Alit Pradina Putri, Pengaruh.....

Desa Di Kota Denpasar.E-Jurnal Manajemen Unud, 6 (10), hlm. 5607-5630

Prasetyo, Dwi Agung dan Darmayanti, Ni Putu Ayu. 2015. Pengaruh Risiko Kredit, Likuiditas, Kecukupan Modal, dan Efisiensi Operasional Terhadap Profitabilitas pada PT BPD Bali. E-Jurnal Manajemen Unud, 4 (9), hal. 2590-2617.

Paulin, Okky And Wiryono, Sudarso Kaderi. 2015. Determinants Of Islamic Bank's Profitability In Indonesia For 2009 - 2013. Journal Of Business And Management, Vol 4, No. 1, pp. 175-185.

Riyadi, Selamat. 2006. Banking Asset And Liability Management, Edisi Ketiga. Jakarta : Fakultas Ekonomi Universitas Indonesia.

Rahman, Mohammad Morshedur, et al., 2015. Determinants of Bank Profitability: Empirical Evidence from Bangladesh. International Journal of Business and Management, 10 (8), pp.135-150.

Ramadanti, Fani dan Meiranto, Wahyu. 2015. Analisis Pengaruh Risiko Likuiditas Terhadap Profitabilitas Perusahaan Perbankan di Indonesia. Diponegoro Journal of Accounting, 4 (2), hal. 1-10.

Santoso, Adi. 2016. Peningkatan Profitabilitas Pada Industri Perbankan Go-Publik Di Indonesia. Esensi: Jurnal Bisnis Dan Manajemen, 6 (1), hal. 1-16.

Sugiyono. 2016. Metode Penelitian Administrasi. Bandung: CV. Alfabeta.

Susanto, Heri dan Kholis, Nur. 2016. Analisis Rasio Keuangan Terhadap Profitabilitas Pada Perbankan Indonesia. Jurnal EBBANK , 7 (1), hal. 1122.

Warsa, Ni Made Inten Uthami Putri Dan Mustanda, I Ketut. 2016. Pengaruh CAR, LDR dan NPL Terhadap ROA Pada Sektor Perbankan Di Bursa Efek Indonesia. E-Jurnal Manajemen Unud, 5 (5), hal. 2842 - 2870.

Wulandari, Luh Putu Fiadevi Dan Sudjarni, Luh Komang. 2014. Pengaruh CAR, $N P L$, dan CR Pada Profitabilitas BPR SE- Kabupaten Gianyar. E-Jurnal Manajemen Universitas Udayana, 3 (1), hlm. 99-116

$\underline{\text { www.bi.go.id }}$ 